\title{
Extraction and identification of synovial tissue-derived exosomes by different separation techniques
}

\author{
Pu Chen ${ }^{1}$, Anmin Ruan ${ }^{1}$, Jun Zhou', Liuwei Huang ${ }^{2}$, Xiaozhe Zhang ${ }^{1}$, Yufeng Ma ${ }^{1}$ and Qingfu Wang ${ }^{1 *}$
}

\begin{abstract}
Objective: The aim of this study is to compare the efficiency of different separation techniques for extracting synovial tissue-derived exosomes.

Methods: The synovial tissue discarded during knee arthroscopy or total knee arthroplasty surgery was collected from the Third Affiliated Hospital of Beijing University of Chinese Medicine. Ultracentrifugation (UC), filtration combined with size exclusion chromatography (SECF), and 8\% polyethylene glycol (PEG) were used to extract synovial tissue-derived exosomes. Transmission electron microscopy (TEM), nanoparticle tracer analysis (NTA), and Western Blot (WB) were used to detect the morphology, particle size, and biomarker proteins (CD9, CD63, Flotillin-1, and calnexin) of exosomes.

Results: The extracts of enriched round and discoid vesicles were successfully extracted with UC, SECF, and PEG. The results of TEM have shown that all three extraction methods can extract circular or elliptical vesicles with discand cup-shaped structures from the synovial tissue, with the diameter is about 30-150 nm. NTA suggested the main peaks of three groups of exosomes are around 100-120 nm, and the concentration of the three groups of exosomes was greater than $1 \times 10^{10} / \mathrm{ml}$. The results of WB showed that three positive protein markers (CD9, CD63, and Flotillin-1) were highly expressed in the suspension extracted by the three methods and low in the synovial tissue. However, the negative protein (calnexin) was highly expressed in synovial tissues and PEG group, while low in UC and SECF group.

Conclusion: Morphology, particle size, and labeled protein marker detection confirmed that UC, SECF, and PEG can extract exosomes derived from synovial tissue; UC and SECF are more recommended for the extraction of synovial tissue-derived exosomes, which provides a methodological basis for studying the function and mechanism of synovial tissue exosomes in the future.
\end{abstract}

Keywords: Exosomes, Extracellular vesicles, Osteoarthritis, Synovial tissues

\section{Introduction}

Osteoarthritis (OA) is a musculoskeletal disease characterized by synovial inflammation, progressive cartilage wear, and subchondral bone hyperplasia $[1,2]$. It was

\footnotetext{
* Correspondence: 13910052566@163.com

'Department of Orthopaedic Surgery, Beijing University of Chinese Medicine Third Affiliated Hospital, No. 51, Xiaoguan Street, Anding Gate, Chaoyang District, Beijing, China

Full list of author information is available at the end of the article
}

reported that $\mathrm{OA}$ is one of the top ten causes of lower limb disability $[3,4]$. For many years, cartilage damage has been considered to be the main pathogenesis of OA. However, with the deepening of research, the important role of soft tissues around the joints such as synovial tissues and fat pad in the pathogenesis of OA has been recognized more and more [2, 5-7]. Recent studies have pointed out that synovial inflammation is a precursor to 
radiological OA [8], has a significant positive correlation with OA symptoms [9], and further aggravates cartilage damage [10]. In the previous study, we investigated the relationship between synovial membrane, articular cartilage, and the innate immune system in different degrees of KOA rats during pathogenesis, and found that the innate immune system is associated with synovial membrane and articular cartilage at all stages of the disease. It also suggests that the synovial membrane may affect the pathological changes of articular cartilage through the innate immune system, thus affecting the progression of OA [11]. However, how synovial tissue affects cartilage, how the synovial inflammatory transmitted between cells and tissues remains to be studied.

Exosomes are $30-150 \mathrm{~nm}$-sized extracellular vesicles, with lipid bilayer membranes, and released by many different types of cells [12]. As reported, exosomes widely existed in various cell supernatants and biological fluids $[13,14]$ such as plasma, serum, cerebrospinal fluid, urine, and milk. They contain many biologically active substances secreted by recipient cells, such as noncording RNA (ncRNA), proteins, and mRNA. And it plays an important role in the extracellular microenvironment and intercellular communication [12, 15-18]. Kato [19] extracted exosomes from the supernatant of IL-1 $\beta$-induced synovial fibroblasts and then added exosomes to chondrocytes. The results showed that the matrix metalloproteinase-13 (MMP-13) was highly upregulated and the type II collagen was significant downregulated, which accelerated the progression of OA. This suggests that synovial tissue may regulate chondrocytes by secreting exosomes. Number of articles [15-22] has conducted detailed studies on how to extract cell supernatants and exosomes in body fluids, but few of articles had studied the extraction and identification of exosomes in tissues. To the best of our knowledge, any article has been published on how to extract and identify exosomes from synovial tissue. Therefore, the purpose of this study was to extract exosomes from synovial tissue by different separation techniques, and then identify and compare the extracted exosomes by transmission electron microscopy (TEM), nanoparticle tracer analysis (NTA), and Western Blot (WB).

\section{Methods}

\section{Main instruments and reagents}

Exosome-free fetal bovine serum was purchased from ABW (Uruguay); Dulbecco's Modified Eagle Medium high-glucose (DMEM-H) was purchased from Hyclone (Boston, USA); antibiotic mixture (penicillin and streptomycin) was obtained from Invitrogen (CA, USA); $0.22 \mu \mathrm{m}$ filter was purchased from Millipore (USA); polyethylene glycol (PEG) 6000 was obtained from Sigma (USA); BCA protein concentration assay kit, constant temperature incubator, and cryostat centrifuge were purchased from Thermo Scientific (USA); size exclusion chromatography and filtration kit were purchased from Echo Biotech (Beijing, China); primary antibodies against CD9, CD63, Flotillin-1, and calnexin were purchased from CST (Cambridge, MA, USA); goat anti-rabbit and goat anti-mouse horseradish peroxidase conjugates were purchased from Bio-Rad Laboratories (Proteintech, USA); inverted phase contrast microscope was obtained from Olympus (Japan); nanoparticle tracking analyzer was obtained from PMX (Germany); transmission electron microscope H-7650 was obtained from Hitachi (Japan).

\section{Collection and treatment of synovial tissue specimens}

The study was approved by the Third Affiliated Hospital of Beijing University of Chinese Medicine and its ethics committee. De-identified discarded human synovial tissue samples were used for this study. From May 2019 to July 2019, a total of 18 samples of synovial tissue were obtained from the discarded synovial tissue of knee arthroscopy or joint replacement surgery in the Third Affiliated Hospital of Beijing University of Chinese Medicine. All patients underwent arthroscopic or joint replacement surgery for primary knee osteoarthritis. Synovial tissue was randomly divided into 3 groups, polyethylene glycol (PEG) group, ultracentrifugation (UC) group, and size exclusion chromatography and filtration (SECF) group, with 6 cases in each group. The synovial tissue obtained during the operation was placed in PBS containing 1\% antibiotic mixture, placed in an ice box, and quickly transferred to a clean bench. Synovial tissue was immediately placed in a new culture dish; PBS containing $1 \%$ antibiotic mixture was added thereto, washed 3 times for 5 min each time. The cleaned synovial tissue was transferred to a new culture dish $(60 \mathrm{~mm})$, cut into pieces of $1 \times 1 \times 1 \mathrm{~mm}^{3}$ by ophthalmic scissors, added 5 - $\mathrm{ml} \mathrm{cul-}$ ture medium (containing 10\% exosome-free fetal bovine serum and $1 \%$ antibiotic mixture), and then placed in constant temperature incubator with $37^{\circ} \mathrm{C}, 5 \% \mathrm{CO}_{2}$. After $24 \mathrm{~h}$, the culture supernatant was collected and the medium was changed, and the supernatant was collected again $24 \mathrm{~h}$ later. The twice collected supernatant was filtered through a $0.22-\mu \mathrm{m}$ filter and then placed in $80{ }^{\circ} \mathrm{C}$ for storage.

\section{Extract exosomes from collected culture supernatant}

For the PEG group, an equal volume of 16\% PEG 6000 solution (with a final solubility of $8 \%$ PEG 6000) was added to the collected medium and overnight at $4{ }^{\circ} \mathrm{C}$. The mixture was centrifuged at $12,000 \times g$ for $30 \mathrm{~min}$ at $4{ }^{\circ} \mathrm{C}$ in the following day, the supernatant was discarded and the pellet was resuspended by PBS. The suspension was centrifuged at $12,000 \times g$ for $30 \mathrm{~min}$ again, resuspended by $\mathrm{PBS}$, and then placed in $-80^{\circ} \mathrm{C}$ for storage. 
For the UC group, the collected medium was centrifuged at $2000 \times g$ for $20 \mathrm{~min}$ to eliminate the cells and then centrifuged at $10,000 \times g$ for $20 \mathrm{~min}$ to eliminate the cell debris, followed by ultracentrifugation at $150,000 \times g$ for $120 \mathrm{~min}$. The supernatant was discarded, resuspended by PBS, and then placed in $-80^{\circ} \mathrm{C}$ for storage.

For the SECF group, all procedures were performed in strict accordance with the kit instructions.

\section{Transmission electron microscopy (TEM)}

To detect the morphology of exosomes, transmission electron microscopy was performed. Take $10 \mu \mathrm{l}$ exosome suspensions on copper grid, after incubating for $10 \mathrm{~min}$ at room temperature, rinse with sterile distilled water and absorb excess liquid from absorbent paper. Then, $10 \mu \mathrm{l}$ of $2 \%$ uranyl acetate was pipetted onto the copper grid for $1 \mathrm{~min}$, and the filter paper was sucked off and dried under an incandescent lamp for $2 \mathrm{~min}$. The copper mesh was observed under transmission electron microscopy and imaged at $80 \mathrm{kV}$.

\section{Nanoparticle tracer analysis (NTA)}

Nanoparticle tracking analysis was performed to determine particle size and concentration of exosomes. Exosome suspensions were appropriately diluted using PBS buffer (with a final concentration of $1 \times 10^{7}-10^{8} / \mathrm{ml}$ ) to measure the particle size and concentration. The suspension is irradiated with a laser light source, and the scattered light of the nanoparticles is detected. The nanoparticle concentration is calculated by counting the number of scattering particles.

\section{Western Blot (WB)}

As described in the previous article [11], after quantified by the BCA protein, each group of exosomes was added to each well and electrophoresed. Subsequently, the protein was transferred to a PVDF membrane, and the 5\% skim milk powder was incubated for $1 \mathrm{~h}$ at room temperature, then incubated with primary antibody $\left(4{ }^{\circ} \mathrm{C}\right.$ overnight or room temperature for $2 \mathrm{~h}$ ), and TBST was washed 4 times for $5 \mathrm{~min}$ each time. Subsequently, the mixture with second antibody was incubated for $1 \mathrm{~h}$ at room temperature, and again washed with TBST for 5 min $\times 8$ times, and ECL was added for development.

\section{Statistical analyses}

Data obtained from this research were presented as the mean \pm standard deviation (SD). All analyses were performed using the GraphPad Prism 7.0 software. The differences between different groups were compared using $t$ test or one-way ANOVA. $P<0.05$ was considered statistically significant.

\section{Results \\ Morphological characteristics of synovial tissue-derived} exosomes

Transmission electron microscopy (TEM) was used to observe the morphology of synovial tissue-derived exosomes. As presented in Fig. 1, all three extraction methods can extract circular or elliptical vesicles with disc- and cup-shaped structures from the synovial tissue, with the diameter is about $30-150 \mathrm{~nm}$, which is consistent with the morphology feature of exosomes. In terms of the background of TEM, the background of PEG group is more blurred and more impurities, while the SECF group is the cleanest, with the least impurities and clearer morphology of exosomes.

\section{Size distribution and concentration of synovial tissue- derived exosomes}

The particle size and concentration of synovial tissuederived exosomes were assessed by nanoparticle tracking analysis (NTA). As shown in Fig. 2, the main peaks of three groups of exosomes are around $100-120 \mathrm{~nm}$. The concentration of the three groups of exosomes was greater than $1 \times 10^{10} / \mathrm{ml}$. The particle size distribution and the cumulative percentage of the interval were presented in Table 1.

\section{Determination of the protein concentration of synovial tissue-derived exosomes with BCA}

The concentration of protein in the three groups of synovial tissue-derived exosomes was measured by BCA assay, measured the absorbance at OD562nm, drawn the standard curve. The protein concentration was determined according to the standard curve equation. As shown in Fig. 3, the UC group had the highest protein concentration, and the SECF group was significantly different from the UC group $(P<$
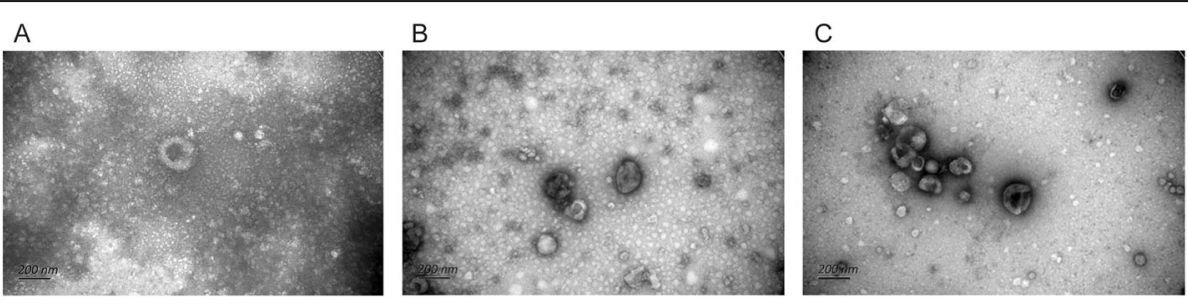

Fig. 1 Morphological characteristics of synovial tissue-derived exosomes extracted by three different extraction methods. a The PEG group. b The UC group. c The SECF group 

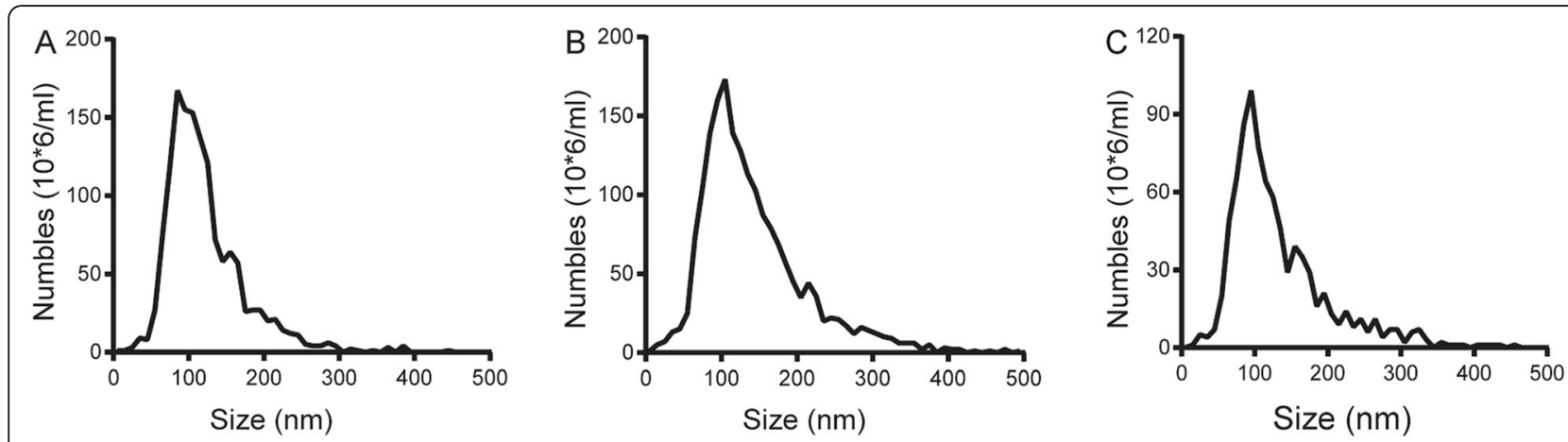

Fig. 2 Morphological characteristics of synovial tissue-derived exosomes extracted by three different extraction methods. a The PEG group. b The UC group. c The SECF group

0.05). No significant difference was found between the PEG group and the other two groups.

The results of exosome biomarker tested by Western Blot The exosome biomarker proteins (CD9, CD63, Flotillin-1, and calnexin) were detected by WB. The results showed that CD9, CD63, and Flotillin-1 were highly expressed in the suspension extracted by the three methods and low in the synovial tissue. However, calnexin was highly expressed in the synovial tissue and PEG group, while low in the UC and SECF group (Fig. 4).

\section{Discussion}

Since mRNA and microRNA were discovered in extracellular vesicles in 2007 , the heat of extracellular vesicles has increased [23]. In particular, after the research on extracellular vesicles award the Nobel Prize in Physiology or Medicine in 2013, the research on the regulation mechanism of cell vesicle transport was a spurt-like growth. Vesicles can be divided into three categories according to origin, biological function, and transformation outcome: apoptotic bodies $(1-4 \mu \mathrm{m})$, microvesicles $(0.1-1 \mu \mathrm{m})$, and exosomes, which are the focus of scholars [24]. As exosomes were initially found in reticulocytes, exosomes were found in cell supernatants such as macrophages, $\mathrm{T}$ lymphocytes, epithelial cells, and nerve cells. Exosomes are also found in blood, semen, ascites, milk, etc. It is currently believed that exosomes are found in almost all mammalian cells and in the body. Exosomes are extremely rich in content. According to statistics, there are currently 9769 proteins, 3408 mRNAs, 1116 lipids, and 2838 microRNAs found in exosomes (www.exocarta.org). These data are mainly derived from early research results, the latest research results have not been included in time and the database was last updated on September 12, 2016. The donor cells secrete exosomes, envelop the target protein, mRNA, and non-cording RNA, received by the recipient cells, and then exerting their intercellular communication and regulatory functions.

With the deepening of exosome research, how to isolate and identify exosomes is one of the important methodological foundations for continued research. At present, a large amount of literature has been published on the extraction of exosomes from cell supernatants and body fluids, such as ultracentrifugation, sucrose density gradient centrifugation, immunomagnetic beads, filtration, ultrafiltration, and various commercial kits. However, few literatures had studied how to extract exosomes from tissues. Lin [25] extracted exosomes from kidney tissue, digested in the kidney, with collagenase and trypsin for $120 \mathrm{~min}$ at $37^{\circ} \mathrm{C}$ then took the supernatant for ultracentrifugation; detected the exosomes with TEM, NTA, and the exosome biomarker proteins (CD9, CD63, and Alix); and then identified as exosomes. Deng [26] extracted exosomes from adipose tissue. After washing with PBS, the adipose tissue was cut into pieces smaller than $4 \mathrm{~mm}$, transferred to a 6-well plate, and added to a DMEM solution containing $1 \%$ antibiotic mixture and $10 \%$ FBS. The supernatant was separated and the exosomes were separated by gradient centrifugation. Beth [27] isolated the extracellular vesicles in the placental tissue, chopped the placenta tissue, placed in the medium, and then placed in a constant temperature incubator for $24 \mathrm{~h}$. The supernatant was collected, and separated the vesicles by ultracentrifugation. Lucia [28] has published a protocol on how to extract exosomes from cell lines and tissues explants, which we have used in our research.

Synovial inflammation, as one of the typical pathological features of $\mathrm{OA}$, plays an important role in the development of OA $[2,5-7,11]$. However, as of now, any article has been published on how to extract and identify exosomes in synovial tissue. Importantly, more and more researchers consider the synovial membrane and intra-articular fat pad as an anatomical unit in OA pathogenesis and pain, and inflammation of synovial membrane in the knee joint may play a central role in OA and affect not only cartilage but also intra-articular fat pad [7, 29, 30]. Moreover, previous 
Table 1 The particle size distribution and the cumulative percentage of the interval

\begin{tabular}{|c|c|c|c|c|c|c|c|c|c|}
\hline \multirow{2}{*}{$\begin{array}{l}\text { Size } \\
(\mathrm{nm})\end{array}$} & \multicolumn{3}{|l|}{ PEG } & \multicolumn{3}{|l|}{ UC } & \multicolumn{3}{|l|}{ SECF } \\
\hline & $\begin{array}{l}\text { Number }\left(10^{6} \text { / }\right. \\
\mathrm{ml})\end{array}$ & $\begin{array}{l}\text { Percent } \\
(\%)\end{array}$ & $\begin{array}{l}\text { Cumulative } \\
\text { percent (\%) }\end{array}$ & $\begin{array}{l}\text { Number }\left(10^{6} /\right. \\
\mathrm{ml})\end{array}$ & $\begin{array}{l}\text { Percent } \\
(\%)\end{array}$ & $\begin{array}{l}\text { Cumulative } \\
\text { percent (\%) }\end{array}$ & $\begin{array}{l}\text { Number }\left(10^{6} /\right. \\
\mathrm{ml})\end{array}$ & $\begin{array}{l}\text { Percent } \\
(\%)\end{array}$ & $\begin{array}{l}\text { Cumulative } \\
\text { percent (\%) }\end{array}$ \\
\hline 5 & 1 & 0.07 & 0.07 & 1.00 & 0.05 & 0.05 & 0.00 & 0.00 & 0.00 \\
\hline 15 & 1 & 0.07 & 0.14 & 5.00 & 0.27 & 0.33 & 1.00 & 0.12 & 0.12 \\
\hline 25 & 3 & 0.21 & 0.35 & 7.00 & 0.38 & 0.71 & 5.00 & 0.58 & 0.69 \\
\hline 35 & 9 & 0.64 & 0.99 & 13.00 & 0.71 & 1.41 & 4.00 & 0.46 & 1.15 \\
\hline 45 & 8 & 0.56 & 1.55 & 15.00 & 0.81 & 2.23 & 7.00 & 0.81 & 1.96 \\
\hline 55 & 27 & 1.91 & 3.46 & 25.00 & 1.36 & 3.59 & 20.00 & 2.30 & 4.26 \\
\hline 65 & 73 & 5.15 & 8.61 & 73.00 & 3.97 & 7.55 & 49.00 & 5.65 & 9.91 \\
\hline 75 & 118 & 8.33 & 16.94 & 105.00 & 5.70 & 13.25 & 65.00 & 7.49 & 17.40 \\
\hline 85 & 167 & 11.79 & 28.72 & 139.00 & 7.55 & 20.80 & 86.00 & 9.91 & 27.30 \\
\hline 95 & 155 & 10.94 & 39.66 & 160.00 & 8.69 & 29.49 & 99.00 & 11.41 & 38.71 \\
\hline 105 & 153 & 10.80 & 50.46 & 173.00 & 9.40 & 38.89 & 77.00 & 8.87 & 47.58 \\
\hline 115 & 137 & 9.67 & 60.13 & 139.00 & 7.55 & 46.44 & 64.00 & 7.37 & 54.95 \\
\hline 125 & 121 & 8.54 & 68.67 & 128.00 & 6.95 & 53.39 & 58.00 & 6.68 & 61.64 \\
\hline 135 & 72 & 5.08 & 73.75 & 113.00 & 6.14 & 59.53 & 46.00 & 5.30 & 66.94 \\
\hline 145 & 58 & 4.09 & 77.84 & 103.00 & 5.59 & 65.13 & 29.00 & 3.34 & 70.28 \\
\hline 155 & 64 & 4.52 & 82.36 & 87.00 & 4.73 & 69.85 & 39.00 & 4.49 & 74.77 \\
\hline 165 & 57 & 4.02 & 86.38 & 79.00 & 4.29 & 74.14 & 35.00 & 4.03 & 78.80 \\
\hline 175 & 26 & 1.83 & 88.21 & 69.00 & 3.75 & 77.89 & 29.00 & 3.34 & 82.14 \\
\hline 185 & 27 & 1.91 & 90.12 & 57.00 & 3.10 & 80.99 & 16.00 & 1.84 & 83.99 \\
\hline 195 & 27 & 1.91 & 92.03 & 45.00 & 2.44 & 83.43 & 21.00 & 2.42 & 86.41 \\
\hline 205 & 20 & 1.41 & 93.44 & 35.00 & 1.90 & 85.33 & 13.00 & 1.50 & 87.90 \\
\hline 215 & 21 & 1.48 & 94.92 & 44.00 & 2.39 & 87.72 & 9.00 & 1.04 & 88.94 \\
\hline 225 & 14 & 0.99 & 95.91 & 36.00 & 1.96 & 89.68 & 14.00 & 1.61 & 90.55 \\
\hline 235 & 12 & 0.85 & 96.75 & 20.00 & 1.09 & 90.77 & 8.00 & 0.92 & 91.47 \\
\hline 245 & 11 & 0.78 & 97.53 & 22.00 & 1.20 & 91.96 & 11.00 & 1.27 & 92.74 \\
\hline 255 & 5 & 0.35 & 97.88 & 21.00 & 1.14 & 93.10 & 6.00 & 0.69 & 93.43 \\
\hline 265 & 4 & 0.28 & 98.17 & 17.00 & 0.92 & 94.02 & 11.00 & 1.27 & 94.70 \\
\hline 275 & 4 & 0.28 & 98.45 & 12.00 & 0.65 & 94.68 & 4.00 & 0.46 & 95.16 \\
\hline 285 & 6 & 0.42 & 98.87 & 16.00 & 0.87 & 95.55 & 7.00 & 0.81 & 95.97 \\
\hline 295 & 4 & 0.28 & 99.15 & 14.00 & 0.76 & 96.31 & 7.00 & 0.81 & 96.77 \\
\hline 305 & 0 & 0.00 & 99.15 & 12.00 & 0.65 & 96.96 & 2.00 & 0.23 & 97.00 \\
\hline 315 & 2 & 0.14 & 99.29 & 10.00 & 0.54 & 97.50 & 6.00 & 0.69 & 97.70 \\
\hline 325 & 1 & 0.07 & 99.36 & 9.00 & 0.49 & 97.99 & 7.00 & 0.81 & 98.50 \\
\hline 335 & 0 & 0.00 & 99.36 & 6.00 & 0.33 & 98.32 & 3.00 & 0.35 & 98.85 \\
\hline 345 & 1 & 0.07 & 99.44 & 6.00 & 0.33 & 98.64 & 0.00 & 0.00 & 98.85 \\
\hline 355 & 0 & 0.00 & 99.44 & 6.00 & 0.33 & 98.97 & 2.00 & 0.23 & 99.08 \\
\hline 365 & 3 & 0.21 & 99.65 & 2.00 & 0.11 & 99.08 & 1.00 & 0.12 & 99.19 \\
\hline 375 & 0 & 0.00 & 99.65 & 5.00 & 0.27 & 99.35 & 1.00 & 0.12 & 99.31 \\
\hline 385 & 4 & 0.28 & 99.93 & 0.00 & 0.00 & 99.35 & 1.00 & 0.12 & 99.42 \\
\hline 395 & 0 & 0.00 & 99.93 & 3.00 & 0.16 & 99.51 & 0.00 & 0.00 & 99.42 \\
\hline 405 & 0 & 0.00 & 99.93 & 2.00 & 0.11 & 99.62 & 1.00 & 0.12 & 99.54 \\
\hline 415 & 0 & 0.00 & 99.93 & 2.00 & 0.11 & 99.73 & 1.00 & 0.12 & 99.65 \\
\hline
\end{tabular}


Table 1 The particle size distribution and the cumulative percentage of the interval (Continued)

\begin{tabular}{|c|c|c|c|c|c|c|c|c|c|}
\hline \multirow{2}{*}{$\begin{array}{l}\text { Size } \\
(\mathrm{nm})\end{array}$} & \multicolumn{3}{|l|}{ PEG } & \multicolumn{3}{|l|}{ UC } & \multicolumn{3}{|l|}{ SECF } \\
\hline & $\begin{array}{l}\text { Number }\left(10^{6} \text { / }\right. \\
\mathrm{ml})\end{array}$ & $\begin{array}{l}\text { Percent } \\
(\%)\end{array}$ & $\begin{array}{l}\text { Cumulative } \\
\text { percent (\%) }\end{array}$ & $\begin{array}{l}\text { Number }\left(10^{6} \text { / }\right. \\
\mathrm{ml})\end{array}$ & $\begin{array}{l}\text { Percent } \\
(\%)\end{array}$ & $\begin{array}{l}\text { Cumulative } \\
\text { percent (\%) }\end{array}$ & $\begin{array}{l}\text { Number }\left(10^{6} /\right. \\
\mathrm{ml})\end{array}$ & $\begin{array}{l}\text { Percent } \\
(\%)\end{array}$ & $\begin{array}{l}\text { Cumulative } \\
\text { percent (\%) }\end{array}$ \\
\hline 425 & 0 & 0.00 & 99.93 & 0.00 & 0.00 & 99.73 & 1.00 & 0.12 & 99.77 \\
\hline 435 & 0 & 0.00 & 99.93 & 1.00 & 0.05 & 99.78 & 1.00 & 0.12 & 99.88 \\
\hline 445 & 1 & 0.07 & 100.00 & 0.00 & 0.00 & 99.78 & 0.00 & 0.00 & 99.88 \\
\hline 455 & 0 & 0.00 & 100.00 & 1.00 & 0.05 & 99.84 & 1.00 & 0.12 & 100.00 \\
\hline 465 & 0 & 0.00 & 100.00 & 0.00 & 0.00 & 99.84 & 0.00 & 0.00 & 100.00 \\
\hline 475 & 0 & 0.00 & 100.00 & 2.00 & 0.11 & 99.95 & 0.00 & 0.00 & 100.00 \\
\hline 485 & 0 & 0.00 & 100.00 & 0.00 & 0.00 & 99.95 & 0.00 & 0.00 & 100.00 \\
\hline 495 & 0 & 0.00 & 100.00 & 1.00 & 0.05 & 100.00 & 0.00 & 0.00 & 100.00 \\
\hline
\end{tabular}

team studies have shown that synovial inflammation may affect articular cartilage damage through the innate immune system, aggravating the course of OA [11]. Therefore, how to separate and extract exosomes from synovial tissue is important for studying the function and mechanism of synovial tissue exosomes.

Although there are various methods for extracting exosomes, each method has its advantages and disadvantages. In 2018, the International Society for Extracellular Vesicles published a guide to extracellular studies [12]. In this article, the International Society for Extracellular Vesicles summarizes the methods of vesicle extraction and classifies them into three categories based on the results of the separation: high recovery and low specificity, intermediate recovery and intermediate specificity, and low recovery and high specificity. We selected one method from each of these three categories to extract synovial tissue exosomes, which were PEG, UC, and SECF. In addition, we selected three positive protein markers (included two transmembrane proteins and one

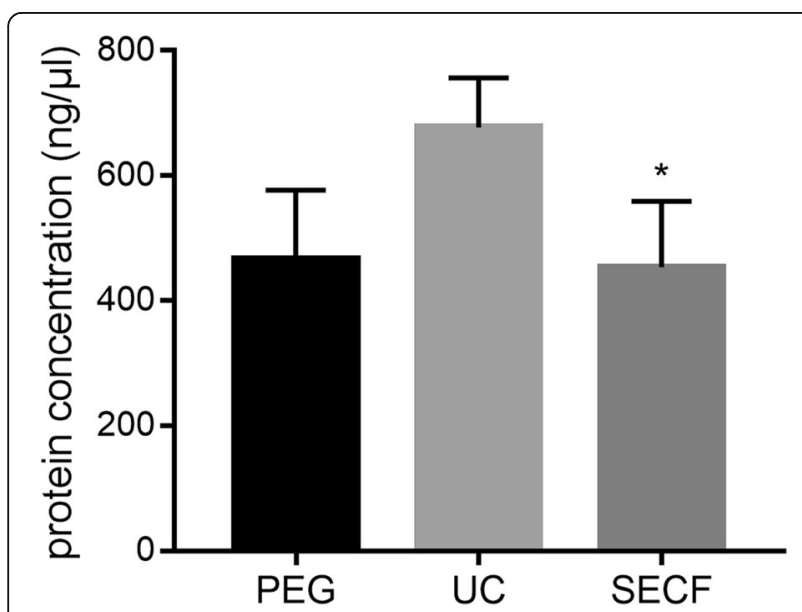

Fig. 3 The protein concentration of synovial tissue-derived exosomes. ${ }^{*}$, compared with the UC group, $P<0.05$ cytosolic protein, CD9, CD63, and Flotillin-1) and one negative protein marker (calnexin) for exosomes indicating markers. The result showed that the positive protein markers were highly expressed in the exosomes and low in synovial tissues, while the negative protein was highly expressed in synovial tissues and PEG group and low in UC and SECF group. This phenomenon may be explained by the fact that PEG can enrich a large amount of impurity proteins, which is also consistent with the recommendations in the guidelines [12], suggesting high concentration and low purity. At the same time, we used TEM and NTA to detect the morphology, particle size, and concentration of exosomes; the results were consistent with the characteristics of exosomes. Therefore, all three methods can extract exosomes from synovial tissue, while PEG group may be doped with a large amount of impurity proteins.

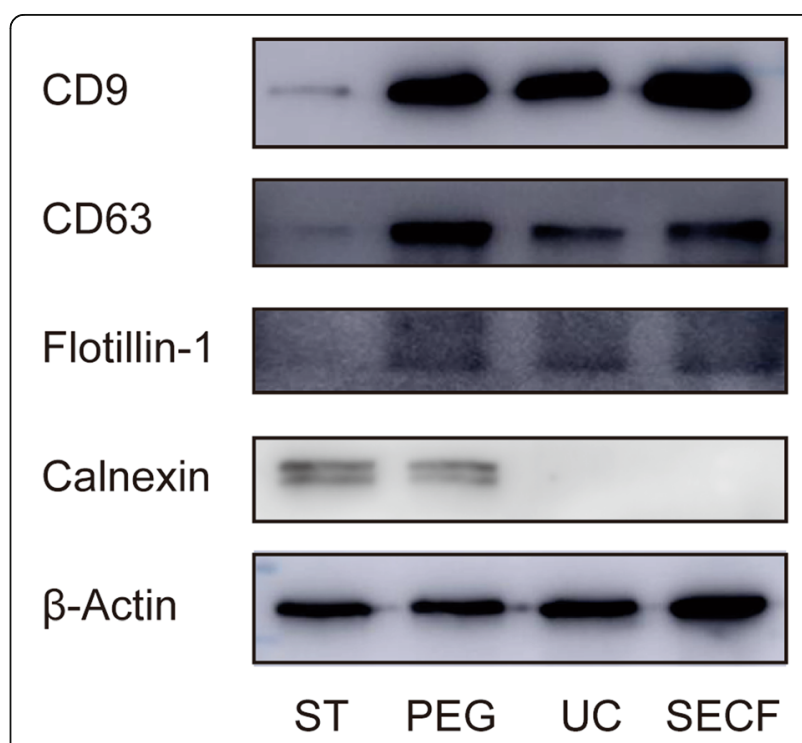

Fig. 4 The exosomes biomarker detection results with WB. ST synovial tissues 
Taken together, UC and SECF are more recommended for the extraction of synovial tissue-derived exosomes, which lays a methodological basis for the subsequent study of the function and mechanism of synovial tissuederived exosomes.

\section{Abbreviations}

NTA: Nanoparticle tracer analysis; OA: Osteoarthritis; PEG: Polyethylene glycol; SECF: Filtration combined with size exclusion chromatography;

TEM: Transmission electron microscopy; UC: Ultracentrifugation; WB: Western Blot

\section{Acknowledgements}

We thank the authors of the included studies for their help.

\section{Authors' contributions}

$P C, A R$, and $Q W$ contributed to the study design. PC, AR, and JZ contributed to the experiment implementation. $\mathrm{PC}, \mathrm{XZ}$, and $\mathrm{YM}$ contributed to data extraction and table-form making. PC and LH contributed to the article writing. QW made the final decision. All authors read and approved the final manuscript.

\section{Funding}

General Program of National Natural Science Foundation of China (no. 81373662)

\section{Availability of data and materials}

All data are fully available without restriction.

\section{Ethics approval and consent to participate}

This article was approved by the Ethics Committee of the Third Affiliated Hospital of Beijing University of Chinese Medicine.

\section{Consent for publication}

Yes.

\section{Competing interests}

The authors declare that they have no competing interests.

\section{Author details}

'Department of Orthopaedic Surgery, Beijing University of Chinese Medicine Third Affiliated Hospital, No. 51, Xiaoguan Street, Anding Gate, Chaoyang District, Beijing, China. ${ }^{2}$ Southern Medical University, Guangzhou, Guangdong Province, China.

Received: 4 December 2019 Accepted: 17 February 2020 Published online: 09 March 2020

\section{References}

1. Malemud CJ. Biologic basis of osteoarthritis: state of the evidence. Curr Opin Rheumatol. 2015;27(3):289.

2. Berenbaum F. Osteoarthritis as an inflammatory disease (osteoarthritis is not osteoarthrosis!). Osteoarthritis Cartilage. 2013;21(1):16-21.

3. Neogi T. The epidemiology and impact of pain in osteoarthritis. Osteoarthritis Cartilage. 2013;21(9):1145-53.

4. Chen $P$, Huang L, Ma Y , Zhang D, Zhang X, Zhou J, Ruan A, Wang $\mathrm{Q}$. Intraarticular platelet-rich plasma injection for knee osteoarthritis: a summary of meta-analyses. J Orthop Surg Res. 2019;14(1):385.

5. Mancarella L, Addimanda O, Cavallari C, Meliconi R. Synovial inflammation drives structural damage in hand osteoarthritis: a narrative literature review. Curr Rheumatol Rev. 2016;13(1):43-50.

6. Ozeki N, Muneta T, Koga H, Nakagawa Y, Mizuno M, Tsuji K, Mabuchi Y, Akazawa C, Kobayashi E, Matsumoto K. Not single but periodic injections of synovial mesenchymal stem cells maintain viable cells in knees and inhibit osteoarthritis progression in rats. Osteoarthritis Cartilage. 2016;24(6):1061-70.

7. Belluzzi E, Stocco E, Pozzuoli A, Granzotto M, Porzionato A, Vettor R, De Caro R, Ruggieri P, Ramonda R, Rossato M. Contribution of infrapatellar fat pad and synovial membrane to knee osteoarthritis pain. \#N/A 2019; 2019.
8. Atukorala I, Kwoh CK, Guermazi A, Roemer FW, Boudreau RM, Hannon MJ, Hunter DJ. Synovitis in knee osteoarthritis: a precursor of disease? Ann Rheum Dis. 2016;75(2):390-5.

9. Guermazi A, Hayashi D, Roemer FW, Zhu Y, Niu J, Crema MD, Javaid MK, Marra MD, Lynch JA, El-Khoury GY, et al. Synovitis in knee osteoarthritis assessed by contrast-enhanced magnetic resonance imaging (MRI) is associated with radiographic tibiofemoral osteoarthritis and MRI-detected widespread cartilage damage: the MOST study. J Rheumatol. 2014;41(3):501-8.

10. Roemer FW, Guermazi A, Felson DT, Niu J, Nevitt MC, Crema MD, Lynch JA, Lewis CE, Torner J, Zhang Y. Presence of MRI-detected joint effusion and synovitis increases the risk of cartilage loss in knees without osteoarthritis at 30-month follow-up: the MOST study. Ann Rheum Dis. 2011;70(10):1804-9.

11. Wang $H$, Wang $Q$, Yang $M$, Yang L, Wang W, Ding H, Zhang D, Xu J, Tang X, Ding $\mathrm{H}$, et al. Histomorphology and innate immunity during the progression of osteoarthritis: does synovitis affect cartilage degradation? J Cell Physiol. 2018;233(2):1342-58.

12. Thery C, Witwer KW, Aikawa E, Alcaraz MJ, Anderson JD, Andriantsitohaina R, Antoniou A, Arab T, Archer F, Atkin-Smith GK, et al. Minimal information for studies of extracellular vesicles 2018 (MISEV2018): a position statement of the International Society for Extracellular Vesicles and update of the MISEV2014 guidelines. J Extracell Vesicles. 2018;7(1):1535750.

13. Foers AD, Chatfield S, Dagley LF, Scicluna BJ, Webb Al, Cheng L, Hill AF, Wicks IP, Pang KC. Enrichment of extracellular vesicles from human synovial fluid using size exclusion chromatography. J Extracell Vesicles. 2018;7(1): 1490145.

14. Johnsen KB, Gudbergsson JM, Skov MN, Pilgaard L, Moos T, Duroux M. A comprehensive overview of exosomes as drug delivery vehicles-endogenous nanocarriers for targeted cancer therapy. Biochim Biophys Acta. 2014;1846(1):75-87.

15. Li D, Liu J, Guo B, Liang C, Dang L, Lu C, He X, Cheung HY, Xu L, Lu C, et al. Osteoclast-derived exosomal miR-214-3p inhibits osteoblastic bone formation. Nat Commun. 2016;7:10872.

16. Yang DW, Qian GB, Jiang MJ, Wang P, Wang KZ. Inhibition of microRNA-495 suppresses chondrocyte apoptosis through activation of the NF-kappaB signaling pathway by regulating CCL4 in osteoarthritis. Gene Ther. 2019.

17. He S, Li Z, Yu Y, Zeng Q, Cheng Y, Ji W, Xia W, Lu S. Exosomal miR-499a-5p promotes cell proliferation, migration and EMT via mTOR signaling pathway in lung adenocarcinoma. Exp Cell Res. 2019.

18. Wu J, Kuang L, Chen C, Yang J, Zeng WN, Li T, Chen H, Huang S, Fu Z, Li J, et al. miR-100-5p-abundant exosomes derived from infrapatellar fat pad MSCs protect articular cartilage and ameliorate gait abnormalities via inhibition of mTOR in osteoarthritis. Biomaterials. 2019;206:87-100.

19. Kato T, Miyaki S, Ishitobi H, Nakamura Y, Nakasa T, Lotz MK, Ochi M. Exosomes from IL-1beta stimulated synovial fibroblasts induce osteoarthritic changes in articular chondrocytes. Arthrit Res Ther. 2014;16(4):R163.

20. Wang L, Wang C, Jia X, Yu J. Circulating exosomal miR-17 inhibits the induction of regulatory $T$ Cells via suppressing TGFBR II expression in rheumatoid arthritis. Cell Physiol Biochem. 2018;50(5):1754-63.

21. Sun H, Hu S, Zhang Z, Lun J, Liao W, Zhang Z. Expression of exosomal microRNAs during chondrogenic differentiation of human bone mesenchymal stem cells. J Cell Biochem. 2019;120(1):171-81.

22. Burke J, Kolhe R, Hunter M, Isales C, Hamrick M, Fulzele S. Stem cell-derived exosomes: a potential alternative therapeutic agent in orthopaedics. Stem Cells Int. 2016;2016:5802529.

23. Valadi H, Ekstrom K, Bossios A, Sjostrand M, Lee JJ, Lotvall JO. Exosomemediated transfer of mRNAs and microRNAs is a novel mechanism of genetic exchange between cells. Nat Cell Biol. 2007;9(6):654-9.

24. Lemoinne S, Thabut D, Housset C, Moreau R, Valla D, Boulanger CM, Rautou PE. The emerging roles of microvesicles in liver diseases. Nat Rev Gastroenterol Hepatol. 2014;11(6):350-61.

25. Lv LL, Feng Y, Wen Y, Wu WJ, Ni HF, Li ZL, Zhou LT, Wang B, Zhang JD, Crowley SD, et al. Exosomal CCL2 from tubular epithelial cells is critical for albumin-induced tubulointerstitial inflammation. J Am Soc Nephrol. 2018; 29(3):919-35.

26. Deng ZB, Poliakov A, Hardy RW, Clements R, Liu C, Liu Y, Wang J, Xiang X, Zhang $S$, Zhuang $X$, et al. Adipose tissue exosome-like vesicles mediate activation of macrophage-induced insulin resistance. Diabetes. 2009;58(11): 2498-505.

27. Holder BS, Tower CL, Forbes K, Mulla MJ, Aplin JD, Abrahams VM. Immune cell activation by trophoblast-derived microvesicles is mediated by syncytin 1. Immunology. 2012;136(2):184-91. 
28. Mincheva-Nilsson L, Baranov V, Nagaeva O, Dehlin E. Isolation and characterization of exosomes from cultures of tissue explants and cell lines. Curr Protoc Immunol. 2016;115:14 42 11-21.

29. Macchi V, Stocco E, Stecco C, Belluzzi E, Favero M, Porzionato A, De Caro R. The infrapatellar fat pad and the synovial membrane: an anatomofunctional unit. J Anat. 2018;233(2):146-54.

30. Eymard F, Pigenet A, Citadelle D, Tordjman J, Foucher L, Rose C, Flouzat Lachaniette CH, Rouault C, Clement K, Berenbaum F, et al. Knee and hip intra-articular adipose tissues (IAATs) compared with autologous subcutaneous adipose tissue: a specific phenotype for a central player in osteoarthritis. Ann Rheum Dis. 2017;76(6):1142-8.

\section{Publisher's Note}

Springer Nature remains neutral with regard to jurisdictional claims in published maps and institutional affiliations.

Ready to submit your research? Choose BMC and benefit from:

- fast, convenient online submission

- thorough peer review by experienced researchers in your field

- rapid publication on acceptance

- support for research data, including large and complex data types

- gold Open Access which fosters wider collaboration and increased citations

- maximum visibility for your research: over $100 \mathrm{M}$ website views per year

At BMC, research is always in progress.

Learn more biomedcentral.com/submissions 